\title{
The Role of Transformational Entrepreneurship, Readiness to Change and Counterproductive Work Behavior in Enhancing Employee Performance
}

\author{
Febri Nila CHRISANTY ${ }^{1}$, Michael Surya GUNAWAN ${ }^{1}$, \\ Retno W. WIJAYANTI' ${ }^{1}$ Budi W. SOETJIPTO ${ }^{1,2}$
}

${ }^{1}$ University of Indonesia, Faculty Economics and Business, Depok, Indonesia, febrinilac@yahoo.com (corresponding author), mbwftafg@gmail.com, retno.wijayanti65@gmail.com, b.soetjipto@gmail.com

${ }^{2}$ University of Pertamina, Faculty Economics and Business, Jakarta, Indonesia

\begin{abstract}
Background and Purpose: The company sustainability balancing economic with social impact to coexist whilst the transformation entrepreneurship create the coexist. The purpose of this research is to better understand the consequences of transformational entrepreneurship, in terms of increasing organizational readiness for change, minimizing counterproductive work behavior and enhancing employee performance. In addition, this paper aims to comprehend the extent to which organizational readiness for change and counterproductive work behavior affect employee performance.

Methodology: The data were collected via a survey of 257 branches of a state-owned bank. The structural equation model (SEM) was used to test the proposed model.

Findings: Transformational entrepreneurship positively and significantly affect organizational readiness for change and employee performance, and negatively and significantly affect counterproductive work behavior. Moreover, the result demonstrated a significantly positive effect of organizational readiness for change on employee performance, and demonstrated a significantly negative effect of counterproductive work behavior on employee performance.

Conclusion: Point of this study is the effectiveness of transformational entrepreneurship in directly affecting employees' performance. However, the effect transformational entrepreneurship has on readiness for change and counterproductive work behavior adds its impact on employees' performance and based on the direct effect, readiness for comes up much more impactful than the other two. It implies how volatile and dynamics the work (internal and external) situations that having employees ready for change can help them cope with such volatility and dynamics to reach better performance.
\end{abstract}

Keywords: Employee performance, Counterproductive work behavior, Readiness for change, Transformational entrepreneurship

\section{Introduction}

A research by Deutsche Bank shows that companies with high ratings for environmental, social, and governance (ESG) factors lead the market in the medium (three to five years) and long (five to ten years) term (Bonini \& Swartz, 2014). According to McKinsey Global Survey, almost six in ten respondents say that their organizations put more emphasis on sustainability than they did two years ago (McKinsey, 2017). These facts indicate the business' attention has shifted toward sustainable environment. In other words, companies now cannot just aim at economic results; they also have to simultaneously consider social impacts. Such co-existence leads us to the concept of transformational entrepreneurship. Transformational entrepreneurs continuously seek and develop innovative solutions not only for the wealth of their company, but also for the well-being of the society. They understand

Received: 2nd October 2020; revised: 15th December 2020; accepted: 12th January 2021 
that their company's success cannot be separated from the growth of the society. Society who are well taken care of will have resources to sustain the company's future development. Transformational entrepreneurs recognize the reciprocal and mutual benefit nature of company-society relationship.

This recognition however will bear consequences, mainly that the company itself must be ready for a change; a change that brings an economic, shorter-term perspective into a socio-economic, longer-term perspective of managing the business. Related to Lewin's (1951) unfreezing, such readiness indicates employees' "beliefs, attitudes and intentions regarding the extent to which changes are needed and the organization's capacity to successfully make those changes" (Armenakis, Harris and Mossholder, 1993, p. 681). In other words, readiness for change is all about employees' conviction on the necessity of change and their company's ability to implement it. Despite the importance of understanding the nature of transformational entrepreneurship-readiness for change connection, little attention has been paid to empirically examine it. For that reason, this study aims at investigating such connection.

Nonetheless, the above consequence may not be well accepted by all employees in the organization. Some may see it as an injustice. Those who have consistently delivered economic results may feel that part of their (future) performance is unfairly taken. Employees who have been credited with high performance in the past may not have as high performance in the future. This decreased performance certainly affect their financials. For these employees and some more others, such financials are their (only) personal goal working in the organization. Shifting to accommodate both economic results and social impacts may be seen as an obstacle to achieve their goal; the goal they have steadily achieved in the past. This potential inability is an instrumental factor for them. Referring to Klandermans $(1997 ; 2002)$, perceived injustice and instrumentality are two primary components of collective protest. Kelloway, Francis, Prosser and Cameron (2010) suggested that counterproductive work behavior depicted such protest. In other words, practices of transformational entrepreneurship could lead employees to engage in counterproductive work behavior. Unfortunately, previous researches have lacked of interest in investigating that plausible connection, and, therefore, empirically examining this connection becomes the objective of this study.

Practices of transformational entrepreneurship and being ready for a possible change all aims at improving employees' performance, which in turn increasing organization's performance. Pradhan and Jena (2017) categorized employees' performance into task performance (performance related to job description and/or employment contract), adaptive performance (performance related to dynamic work situation, such as technological changes), and contextual performance (performance related to maintaining and developing prosocial or helping behavior). To the best of the authors' knowledge, no empirical study has been conducted to examine the effect of transformational entrepreneurship on employees' performance. Meanwhile, Weeks, Roberts, Chonko and Jones (2004) demonstrated a positive and significant association between organizational readiness for change and job performance in sales organizations. Job performance examined in this study was essentially task performance. No studies have been found that connect organizational readiness for change and adaptive performance, as well as contextual performance. Consequently, this study investigates the effect of each transformational entrepreneurship and organizational readiness for change on employees' performance, in terms of task, adaptive and contextual performances.

On the other hand, as an indicative of protests, counterproductive work behavior may result in lower employees' performance. Sackett (2002) identified some findings with regard to this effect on big three data sets. The first one was the US Army Selection and Classification Project (called Project A), which he found a low relationship between counterproductive work behavior (-.19) and task performance $(-, 17)$, in terms of core technical and general soldiering proficiencies, but a much higher relationship (-.59) between counterproductive work behavior and contextual performance, in terms of citizenship behavior. In the second data set was from Hunt's (1996). This data set demonstrates a similar relationship (-.67) between counterproductive work behavior and contextual performance, in terms of citizenship behavior. From the third data set (Viswesvaran, Schmidt and Ones' (1999) meta-analysis), he found a much higher relationship (-.54) between counterproductive work behavior and task performance, in terms of job knowledge, quantity of output and quality of output, but a consistent relationship (-.57) between counterproductive work behavior and contextual performance, in terms of citizenship behavior. Furthermore, Greenidge, Devonish and Alleyne (2015) found rather high correlations (-.36 and .40) between counterproductive work behavior (toward the organization and toward the individuals) and contextual performance. Previous research however has not provided result for counterproductive work behavior-adaptive performance relationship. This study therefore empirically examines the effect of counterproductive work behavior on adaptive performance, as well as on task and contextual performances.

This study is conducted in a state-owned bank in Indonesia. Banks have been known to serve a wide range of people and thus to provide economic and social benefits to people. Therefore, ESG factors are not new to them and the shift to include such factors is inevitable. However, the pull for achieving higher financial performance is not getting weaker as the competition in banking industry 
is tighter. In other words, banks are at a cross road: keep pumping higher financial performance or compromise financial performance to accommodate social impacts. This position implies a need for practicing transformational entrepreneurship to simultaneously achieve economic results and social impact, and it brings up a need for readiness to change and a risk for encountering counterproductive work behavior. Banks are therefore considered an appropriate context for this study. Accordingly, this study attempts to answer these research questions:

RQ1. How does transformational entrepreneurship affect the organizational readiness for change?

RQ2. How does transformational entrepreneurship affect the employee performance?

RQ3. How does transformational entrepreneurship affect the counterproductive work behavior?

\section{Sustainability and Transformational Entrepreneurship}

Environmental Performance Index (EPI) (2020) recently releases global metrics for the environment. Among many findings, one is the most important for businesses, that is, "the pursuit of economic prosperity - manifested in industrialization and urbanization - often means more pollution and other strains on ecosystem vitality" (EPI, 2020, p. 1). In other words, there seems to be a contradiction between economic or financial prosperity and social welfare. If economy prospers, social will suffer, and vice versa. The ultimate impact of this contradiction is continual reduction to quality of all life, including human life. This continuous quality degradation will decrease human productivity, that in turn will inhibit the companies to grow. In other words, the pursuit of economic prosperity will likely have a boomerang effect when social welfare is ignored. The prosperity the companies try hard to generate may therefore be short-lived.

To create a long-term success, companies must build their business around environment and social considerations. Starik \& Rands (1995) called this effort and all other efforts to survive by developing their ability to exist and flourish in a long term as a sustainability. Weber (2017) found a positive relationship between financial performance and sustainability performance. With a more balance between both performances, company's success can be cascaded to the prosperity of the society (Maas, Jones \& Lockyer, 2019). A prosper society will be potential consumers to back the company's growth. So, a prosper society could further prosper the companies, and economic prosperity does not have to be in contrast with social welfare.

Entrepreneurship has been known to lead the companies to the discovery, evaluation and exploitation of opportunities (Shane \& Venkataraman, 2000). Entrepreneurship, however, has also been known to be related more to businesses. Scholars then developed a concept of social entrepreneurship. It was Robert Owen, a philanthropic businessman, who first introduced social entrepreneurship in the eighteenth and nineteenth centuries when he paid more attention to employees' welfare, in terms of their working, education and cultural lives (Shaw \& Carter, 2007). In a later development, social entrepreneurship has broadened its focus toward "work of community, voluntary and public organizations, as well as private firms working for social rather than for-profit objectives" (Shaw \& Carter, 2007, p. 419). Consequently, "its impact has been limited to date as its solutions are rarely devised with scalability and true economic sustainability in mind" (Marmer, 2012, p. 2). In other words, social entrepreneurship does not deal with transformation of a profit-motive institution (e.g. the company) to also include social perspective in its objectives.

Transformational entrepreneurship came into consideration when there is a need for individuals, communities and institutions to interact and collaborate for taking advantage of the existing opportunities and reaching a broader scale (Maas et al., 2019; Schoar, 2010). Transformational entrepreneurship develops entrepreneurial activities that bring major changes in market and industry as well as in social and cultural life (Marmer, 2012). Mass and Paul (2019) further delineated that transformational entrepreneurship puts more emphasis on stimulating socio-development in a dynamic manner, while Schoar (2010) envisioned transformational entrepreneurship to create large, vibrant business that grow much beyond the scope of an individual's subsistence needs and provide jobs and income for others. Past literature found that transformational entrepreneurship is characterized by high quality human capital, high willingness to take risk, and high responsiveness to environment (Mass \& Paul, 2019; Herrera \& Lora, 2005; Schoar, 2010). Without qualified people and consideration of external conditions, risking to take advantage of the opportunities will not be worth.

\section{Consequences of Transformational Entrepreneurship}

What differentiates transformational entrepreneurship from entrepreneurship is the scope. Transformational entrepreneurship broadens the scope of entrepreneurship from businesses to communities and societies so that provides the opportunities for companies to create social impacts. Realizing these opportunities may, however, require employees to master a different skill set. Before conforming to this requirement or expectation, employees must accept it. Holt, Armenakis, Harris and Feild (2007), conforming and accepting are two stages of change, where 
conforming is the adoption and accepting is the readiness. In other words, for companies to implement transformational entrepreneurship, their employees must be ready to master the new skill set. This new skill set is a change for them. Part of readiness is upper management's communication to employees explaining why and how such new skill set will improve their subsequent performance. Another part of readiness concerns with company's willingness to invest time, effort and money to upgrade employees' skill set. Therefore, readiness for change involves commitment for both sides: on employees' side, they have to be committed to learn and master the new skill set, and on companies' side, they have to be committed to invest in employees' training. Correspondingly, we can conclude that:

H1: Transformational entrepreneurship positively affects organizational readiness for change

As previously indicated, the introduction of transformation entrepreneurship is not merely to create social impacts. It is farther than that; it is to generate sustainable success for companies, which means sustainable success for employees as well. In other words, the introduction of transformation entrepreneurship is actually to improve employees' performance, that is not only task performance, but also adaptive performance and contextual performance (Pradhan and Jena, 2017). Task performance will be enhanced because employees are able to perform above and beyond what are required by job description, adaptive performance will be better because employees are able to cope with the shift toward generating both economic prosperity and social welfare, and contextual performance will be increased because employees are able to demonstrate prosocial behavior when solving new problems and overcoming new challenges. Subsequently, we propose the hypothesis below:

$\mathrm{H} 2$ : Transformational entrepreneurship positively affects employees' performance.

Companies' practice of transformational entrepreneurship may not however be well accepted by employees. They may see this practice as unfair because they have been resulting good economic performance for a number years, and suddenly they have to shift gear to also create social impacts. As a consequence, they have to spend time and effort to upgrade their skills. Not all employees are willing to spend that much time and effort, and not all employees are capable of upgrading their skills. Their work life that has so far been routine and predictable, now it seems uncertain and unclear. Employees who have sufficiently performed in the past, may not be able to reach that point in the future. It is like their future, predicted performance is taken away from them. This possible lowered performance could affect their take home income. So, practicing transformational entrepreneurship can be seen as a stumbling block to realize employees promised wealthy future and such inability becomes instrumental for their life. Klan- dermans (1997; 2002) argued that (perceived) injustice and instrumentality are core elements of collective protest, and this protest is an indicative of counterproductive work behavior (Kelloway, et al., 2010). For those reasons, the following hypothesis is presented:

H3: Transformational entrepreneurship negatively affects counterproductive work behavior.

\section{Readiness for Change, Counterproductive Work Behavior and Employee Performance}

A well-known scholar in change, Kurt Lewin (1947), introduced three stages of change. They are unfreezing, moving, and refreezing. Lewin classified change itself as moving, so before change is conducted, people must go to unfreezing stage. This is the stage where readiness is developed by shifting the mindsets and generating motivations to change (Weiner, 2009). Weiner further argued that readiness for change involves change commitment and change efficacy, which essentially relate to willingness and ability to implement change. Moreover, readiness for change concerns with benefits of change (Prochaska, Velicer, Rossi, Goldstein, Marcus, Rajiowski, Eiore, Harlow, Redding, Rosenbloom and Rossi, 1994), risks of failing to change (Armenakis et al., 1993; Beer, 1980; Spector, 1989), or externally forced changes (Pettigrew, 1987). If benefits are high and risks are low, readiness are more likely. But, for externally forced changes, readiness may not be a choice because if organizations and their employees are not ready, they may be extinct. Armenakis et al. (1993) further argued that, ultimately, readiness was all about behavior. People's beliefs, attitudes and attentions may have accepted change, but they do not show it in their behavior, they are not considered ready for change. It is with this behavior people implement change.

In addition, Weeks, Roberts, Chonko and Jones (2004) found that when organizations are ready to implement change, their employees are likely to show better performance. Helmy, Adawiyah and Setyawati (2020) also found that the workplace friendship has a significant influence on innovative service behavior. This is due to the fact that these employees are well prepared by their organizations to deal with change, are ensured the benefits and risks of change, and are confident their organization will help and assist them in overcoming challenges and obstacles that can impede their performance. In other words, organizations' readiness for changes is believed to support their employees to implement change that eventually lead to their increased performance. Consequently, we formulate the following hypothesis:

$\mathrm{H} 4$ : Organizational readiness for change positively affects employee performance. 
On the other hand, as discussed previously, not all employees are happy and satisfied with the policies and decisions of the organization, especially when a possible change is involved because change can put them in an unfair and unfortunate position. They can express their unhappiness and dissatisfaction by protesting in the form of behaving counterproductively to attract attention to the policy and decision makers with the hope that unfavorable policies and decisions will be revised and redressed. This counterproductive behavior includes keep complaining on seemingly unimportant matters, make a problem bigger than it should be, and focus on negative aspects of works, which ultimately drag employees away from their targets or objectives. Instead of paying attention to how to carry out their job above and beyond what are required by job description, to create both economic prosperity and social welfare, and to solve new problems and overcome new challenges, they intentionally slow down the work or even sabotage it. Employees who demonstrate counterproductive work behavior will likely not achieve their targets. Furthermore, Sackett (2002) found that counterproductive work behavior might result in lower employees' performance. $\mathrm{He}$, for instance, found negative relationships between counterproductive work behavior and task and contextual performances in three occasions. Greenidge, Devonish and Alleyne (2014) found a similar correlation between counterproductive work behavior and contextual performance. Because of that, we hypothesize as follows:

H5: Counterproductive work behavior negatively affects employee performance.

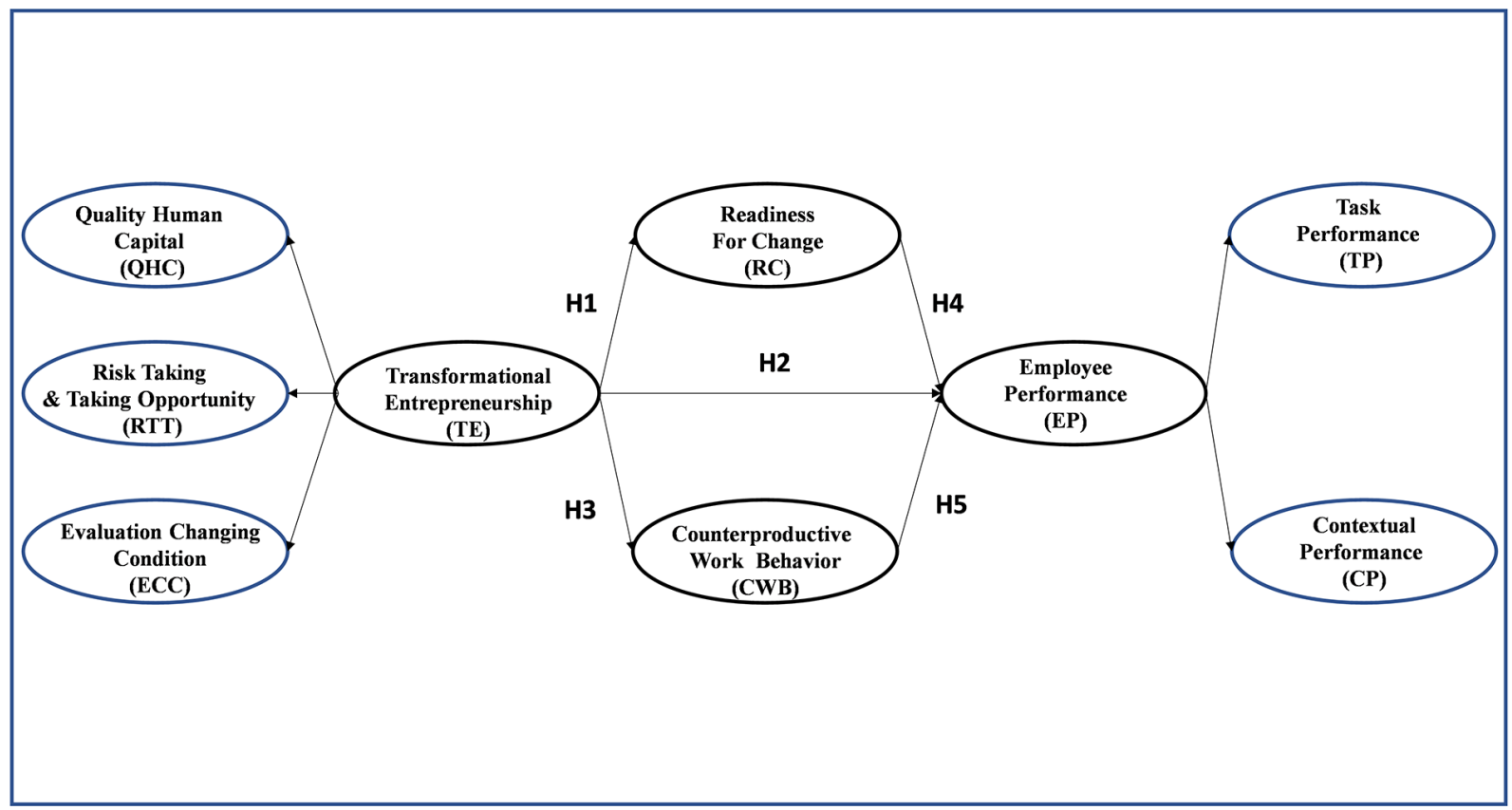

Figure 1: Research Model

\section{Methods}

\subsection{Measures}

Measure for each variable was adapted from literature of respective variable. Measure for transformational entrepreneurship variable was adapted from Maas et al., (2019), Marmer (2012), Schoar (2010), and Virmani and Lepineux (2016). Measure for readiness for change variable was adapted from Armenakis et al., (1993). Measure for counterproductive work behavior variable was adapted from Koopmans, Bernaards, Hildebrandt, Buuren, van der Beek, and de Vet (2014). Measure for employee performance variable was adapted from Pradhan and Jena (2017). Response for each item was measured using a seven-point Likert-scale ranging from (1) "strongly disagree" to (7) "strongly agree".

The constructs employed in this study consist of: Transformation Entrepreneurship (TE), Readiness for Change (RC), Counterproductive Work Behavior (CWB) and Employee Performance (EP). The dimensions of each constructs are: Transformation Entrepreneurship (TE) consist of: a. Human Capital Quality (HCQ), b. Risk Taking \& Taking Opportunity (RTT) and c. Evaluating Changing Condition (ECC) whilst the dimensions of Employee Performance (EP) consist of: a. Task Performance (TP), b. Contextual Performance (CP) and c. Adaptive Perfor- 
mance AP).

Readiness for change and Counterproductive Work Behavior variables were categorized as First Order Confirmatory Factor Analysis (CFA) since they were measured directly from indicators (without any dimension). Whilst Transformational Entrepreneurship and Employee Performance variables were categorized as Second Order CFAs since they each had dimensions. The detail relationship of constructs, dimensions and items measured in this study may be seen in Appendix.1

\subsection{Sample and Data Collection}

Data were collected through online survey to 468 branches (four people from each branch: one branch head and his or her three direct managers). So, in total, there were 468 branch heads and 1,404 branch managers we invited to participate in the survey. We followed up the online survey with phone calls and emails as reminders for them give their response. From total population of 468 branches, we received responses from 330 branches (1.582 samples), but 73 of those branches were incomplete. So, only 257 branches were counted for this study, comprised of 890 respondents (257 branch heads and 633 managers), indicating of 56 percent effective response rate. The respondent profile may be seen in Table 1 and 2 .

If we compared the demographic characteristics of branch head respondents to that of population, they are not much different. The majority of both is between 30 to 40 years old, male, holding a bachelor degree, married, having 3 to 5 dependents, and having 11 to 25 years of

Table 1: Respondents and Population Profile

\begin{tabular}{|c|c|c|c|c|}
\hline \multirow[t]{2}{*}{ Characteristic } & \multicolumn{2}{|c|}{ Branch Manager } & \multicolumn{2}{|c|}{$\begin{array}{c}\text { Total Population Branch Man- } \\
\text { ager }\end{array}$} \\
\hline & Number & Percentage & Number & Percentage \\
\hline \multicolumn{5}{|l|}{ 1. Ages of respondents } \\
\hline$<30$ years & 0 & 0.00 & 0 & $0 \%$ \\
\hline $30-40$ years & 114 & 44.36 & 144 & $44 \%$ \\
\hline$>40-50$ years & 101 & 39.30 & 124 & $38 \%$ \\
\hline$>50$ years & 42 & 16.34 & 62 & $19 \%$ \\
\hline \multicolumn{5}{|l|}{ 2. Gender of respondents } \\
\hline Male & 247 & 96.11 & 317 & $96 \%$ \\
\hline Female & 10 & 3.89 & 13 & $4 \%$ \\
\hline \multicolumn{5}{|l|}{ 3. Education of respondents } \\
\hline Senior High School or below & 0 & 0.00 & 0 & $0 \%$ \\
\hline Bachellorate & 2 & 0.78 & 2 & $1 \%$ \\
\hline Bachelor Degree & 213 & 82.88 & 276 & $84 \%$ \\
\hline Master Degree or above & 42 & 16.34 & 52 & $16 \%$ \\
\hline \multicolumn{5}{|l|}{ 4. Status } \\
\hline Single & 8 & 3.11 & 9 & $3 \%$ \\
\hline Ever been married & 2 & 0.78 & 2 & $1 \%$ \\
\hline Married & 247 & 96.11 & 319 & $97 \%$ \\
\hline \multicolumn{5}{|l|}{ 5. The number of dependents } \\
\hline 0-2 people & 97 & 37.74 & 112 & $34 \%$ \\
\hline 3-5 people & 156 & 60.70 & 212 & $64 \%$ \\
\hline$>5$ people & 4 & 1.56 & 6 & $2 \%$ \\
\hline
\end{tabular}


Table 1: Respondents and Population Profile (continues)

\begin{tabular}{|c|c|c|c|c|}
\hline \multicolumn{5}{|l|}{ 6. Work Experience } \\
\hline $0-5$ years & 1 & 0.39 & 1 & $0 \%$ \\
\hline $6-10$ years & 39 & 15.18 & 49 & $15 \%$ \\
\hline $11-15$ years & 68 & 26.46 & 85 & $26 \%$ \\
\hline $16-20$ years & 64 & 24.90 & 80 & $24 \%$ \\
\hline $21-25$ years & 51 & 19.84 & 68 & $21 \%$ \\
\hline $26-30$ years & 18 & 7.00 & 24 & $7 \%$ \\
\hline$>30$ years & 16 & 6.23 & 23 & $7 \%$ \\
\hline Total & 257 & & 330 & \\
\hline
\end{tabular}

Table 2: Respondents and Population Profile

\begin{tabular}{|c|c|c|c|c|}
\hline \multirow[t]{2}{*}{ Characteristic } & \multicolumn{2}{|c|}{ Branch Manager } & \multicolumn{2}{|c|}{$\begin{array}{c}\text { Total Population Branch Man- } \\
\text { ager }\end{array}$} \\
\hline & Number & Percentage & Number & Percentage \\
\hline \multicolumn{5}{|l|}{ 1. Ages of respondents } \\
\hline$<30$ years & 0 & 0.00 & 4 & $0 \%$ \\
\hline $30-40$ years & 46 & 17.90 & 481 & $38 \%$ \\
\hline$>40-50$ years & 189 & 73.54 & 428 & $34 \%$ \\
\hline$>50$ years & 22 & 8.56 & 339 & $27 \%$ \\
\hline \multicolumn{5}{|l|}{ 2. Gender of respondents } \\
\hline Male & 521 & 82.31 & 1.016 & $81 \%$ \\
\hline Female & 111 & 17.54 & 236 & $19 \%$ \\
\hline \multicolumn{5}{|l|}{ 3. Education of respondents } \\
\hline Senior High School or below & 3 & 0.47 & 20 & $2 \%$ \\
\hline Bachellorate & 218 & 34.44 & 52 & $4 \%$ \\
\hline Bachelor Degree & 246 & 38.86 & 1,126 & $90 \%$ \\
\hline Master Degree or above & 166 & 26.22 & 54 & $4 \%$ \\
\hline \multicolumn{5}{|l|}{ 4. Status } \\
\hline Single & 19 & 3.00 & 42 & $3 \%$ \\
\hline Ever been married & 17 & 2.69 & 19 & $2 \%$ \\
\hline Married & 597 & 94.31 & 1,191 & $95 \%$ \\
\hline \multicolumn{5}{|l|}{ 5. The number of dependents } \\
\hline 0-2 people & 285 & 45.02 & 553 & $44 \%$ \\
\hline 3-5 people & 337 & 53.24 & 669 & $53 \%$ \\
\hline$>5$ people & 11 & 1.74 & 30 & $2 \%$ \\
\hline \multicolumn{5}{|l|}{ 6. Work Experience } \\
\hline $0-5$ years & 3 & 0.47 & 11 & $1 \%$ \\
\hline
\end{tabular}


Table 2: Respondents and Population Profile (continues)

\begin{tabular}{|r|r|r|r|r|}
\hline $6-10$ years & 153 & 24.17 & 285 & $23 \%$ \\
\hline $11-15$ years & 100 & 15.80 & 193 & $3 \%$ \\
\hline $16-20$ years & 170 & 26.86 & $27 \%$ \\
\hline $21-25$ years & 108 & 17.06 & 210 & $17 \%$ \\
\hline & $26-30$ years & 61 & 9.64 & $10 \%$ \\
\hline Total & & 38 & 6.00 & 85 \\
\hline
\end{tabular}

working experience. In essence, branch head respondents represent the population.

The same is true for branch manager respondents. The majority of respondents and population is between 30 to 40 years old, male, holding a bachelor degree, married, having 3 to 5 dependents, and having 16 to 20 years of working experience. In essence, branch manager respondents represent the population.

\section{Analyses and Results}

Data collected from the online survey were analyzed in two steps. The first is measurement model analysis, in which validity and reliability of each measure was tested. The second is structural model analysis, in which the research model was examined using structural equation model (SEM). The detail of each step is elaborated below.

\subsection{Measurement Model Analysis}

Measurement model analysis is to ensure the validity and reliability of all measurements (indicators, dimensions and variables). This study uses standardized factor loading (SFL) as a threshold for validity, where a good validity had $\mathrm{SFL} \geq 0.50$ (Hair, Black, Babin, Anderson, and Tatham, 2014). Measurement with SFL $<0.50$ is considered as invalid and will be dropped and will not be used in measurement models. This study uses construct reliability (CR) and variance extracted (VE) to indicate measurement reliability. A good reliability is where $\mathrm{CR} \geq 0.70$ and $\mathrm{VE} \geq$ 0.50 .

SFL of all measurements were in the range of 0.69 1.00 , except for adaptive performance $(-0.08)$. Hence, our measurement model was valid except for adaptive performance dimension in employee performance (EP_AP) since its SFL was $<0.5$ and for that reason adaptive performance was dropped from measurement model. To evaluate discriminant validity, we analyzed the relationship between square correlation and AVE. As shown in Table 3, AVE for all variables (diagonal and italics) are higher than the corresponding correlations between those variables, suggesting that there is no issue of discriminant validity in our measurement model (Fornell and Larcker, 1981). $\mathrm{CR}$ of all measurements were in the range of 0.86-1.00,

Table 3: Discriminant Validity

\begin{tabular}{|l|c|c|c|c|}
\hline & Readiness for Change & $\begin{array}{c}\text { Employees' Perfor- } \\
\text { mance }\end{array}$ & $\begin{array}{c}\text { Counterproductive } \\
\text { Work Behavior }\end{array}$ & $\begin{array}{c}\text { Transformational } \\
\text { Entrepreneurship }\end{array}$ \\
\hline $\begin{array}{l}\text { Transformational } \\
\text { Entrepreneurship }\end{array}$ & 0.0324 & 0.2809 & 0.0676 & 0.69 \\
\hline $\begin{array}{l}\text { Counterproductive } \\
\text { Work Behavior }\end{array}$ & 0,16 & 0.2916 & 1 & \\
\hline $\begin{array}{l}\text { Employees' Perfor- } \\
\text { mance }\end{array}$ & 0.05476 & 0.83 & & \\
\hline Readiness for Change & 1 & & & \\
\hline
\end{tabular}


whilst VE were in range of $0.68-1.00$. Therefore, all measurements were reliable.

Latent variable score (LVS) is calculated to simplify models based on the item parceling concept (Bandalos, 2002; Jöreskog, 2000; Jöreskog, Sorbom and Walentin, 2006; Rhemtulla, 2016). LVS transforms the Second Order to First Order CFAs. In this study, the dimensions will transform to the First Order CFAs. Item parceling was needed because the measurement model initially had 88 indicators, which required five times the number of indicator (440 branches) (Bentler and Chou, 1987), while participated branches was only 257 . By item parceling, the number indicators were reduced to seven indicators, and the actual sample was then way above the requirement $(257>35)$. Item parceling yielded a more stable estimation of parameters for a small sample (Bandalos, 2002) and improved the model's fit.

\subsection{Structural Model Analysis}

We performed structural model analysis using LISREL
8.8. We first evaluated goodness-of-fit indices (GOFIs) Root Mean Square Error of Approximation (RMSEA), Non-Normed Fit Index (NNFI), Confirmatory Fit Index (CFI), Incremental Fit Index (IFI), Standardized Root Mean Squared Residual (SRMR) and Goodness of Fit Index (GFI). Table 4 provides the result of overall fit evaluation. All six GOFIs show good fit. The structural model's overall fit is hence good.

We then conducted path analysis. Figure 2 and Table 5 show the results of hypotheses testing. Hypotheses are supported when t-value $\geq 1.96$ or $\square-1.96$. As can be seen, all hypotheses are accepted. Support for $\mathrm{H} 1$ (coefficient $=$ 0.17 , t-value $\geq 1.96, \mathrm{p}<0.05$ ) means transformational entrepreneurship positively affects organizational readiness for change. This support indicates that employees accept the fact that implementing transformational entrepreneurship requires then to master a new, different skill set. It also demonstrates employees' commitment to learn such skill set. On the other hand, the organization where they work

Table 4: Goodness of Fit Indices (GOFI)

\begin{tabular}{|l|c|c|}
\hline \multicolumn{1}{|c|}{ GOFI } & Criteria for Good Fit & Value \\
\hline RMSEA & $\leq 0,08$ & 0.0 \\
\hline NNFI & $\geq 0.90$ & 1.00 \\
\hline CFI & $\geq 0.90$ & 1.00 \\
\hline IFI & $\geq 0.90$ & 1.00 \\
\hline RFI & $\geq 0.90$ & 0.98 \\
\hline SRMR & $\leq 0,05$ & 0.013 \\
\hline GFI & $\geq 0.90$ & 0.99 \\
\hline Norm $\chi^{2}$ & $\leq 3$ & 0.88 \\
\hline
\end{tabular}

must be willing and committed to invest time, effort and money to upgrade their skills.

Support for H2 (coefficient $=0.36, \mathrm{t}$-value $\geq 1.96, \mathrm{p}$ $<0.05$ ) means transformational entrepreneurship positively affects employees' performance. This support indicates that transformational entrepreneurship indeed leads the employees to better performance, particularly task and contextual performances. Task performance is better as employees perform above and beyond what are required by job description, and contextual performance is better as employees demonstrate prosocial behavior when solving new problems and overcoming new challenges. Such an increase in performance may be due the direction of transformation entrepreneurship to generate social impacts, which are mostly above and beyond what are required by job description, as well as new problems and challenges for employees.

Support for H3 (coefficient $=-0.26$, t-value $\square-1.96$, $\mathrm{p}<0.05)$ means transformational entrepreneurship negatively affects counterproductive work behavior. This support shows that transformational entrepreneurship may not however be well accepted by employees, especially those who have been resulting good economic performance for a number of years. These employees suddenly have to shift gear to also create social impacts, and, thus have to spend time and effort to upgrade their skills. They may not be capable of upgrading their skills as well. Their work life may no longer be routine and predictable like before; it not may become uncertain and unclear. With this new area of performance, employees' past good performance may not 
matter at present. They may therefore feel like their future, predicted performance based on their past performance, as well as their future take home income, are taken away from them. In other words, transformational entrepreneurship may be seen as a stumbling block for employees to realize their wealthy future. For that reason, employees may silently and collectively protest to the organization they work for (Klandermans, 1997; 2002) in the form of counterproductive work behavior (Kelloway, et al., 2010).

Support for H4 (coefficient $=0.60$, t-value $\geq 1.96, \mathrm{p}<$ $0.05)$ means organizational readiness for change positively affects employees' performance. This support shows that organizational readiness for change leads the employees to better performance as well, particularly task and contextual performances. It also indicates that employees consider change are beneficial for them and the risks associated with it are acceptable (Armenakis et al., 1993; Beer, 1980; Prochaska, et al., 1994; Spector, 1989), so they are committed to it by improving their efficacy to execute change that lead to better performance. Such commitment may be due to the fact that employees are confident their organization will help and assist them in overcoming challenges and obstacles related to change that can impede their performance. In addition, the finding of this study is consistent with what Weeks et al. (2004) found that when organ-

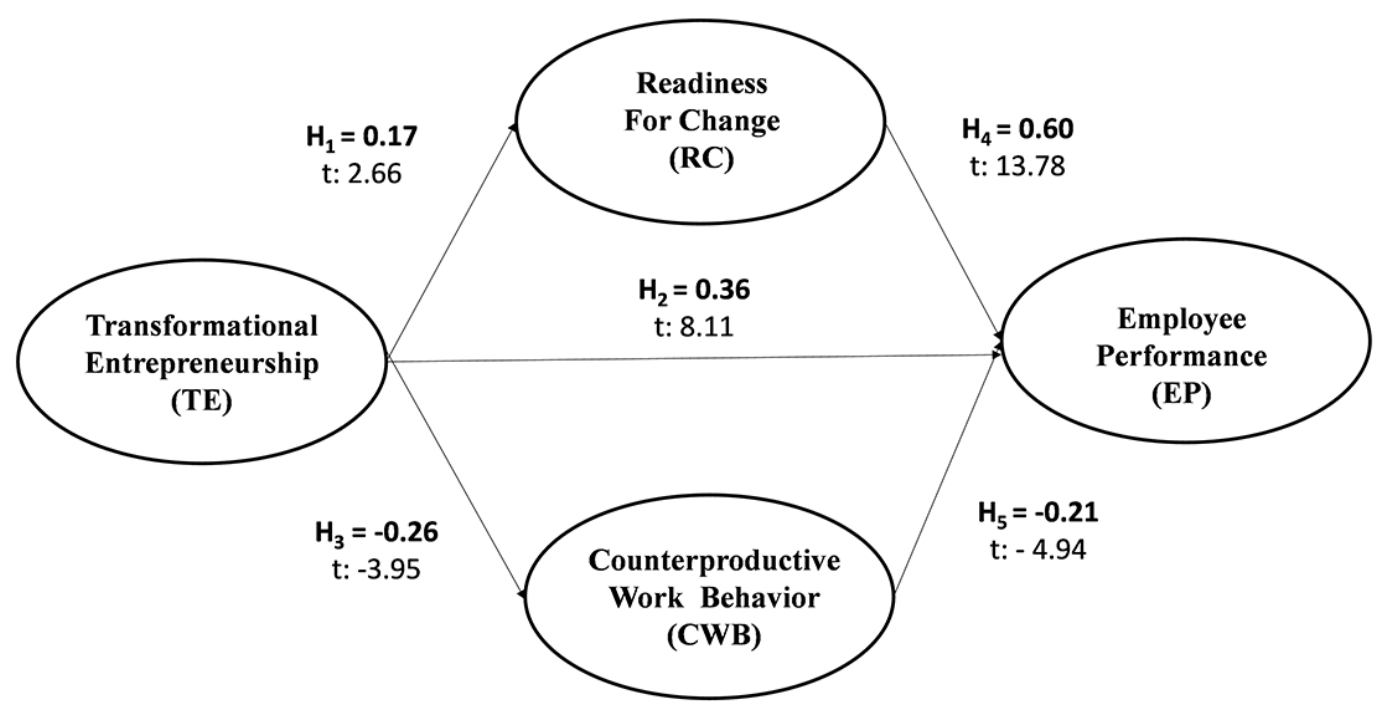

Figure 2: Path Diagram

Table 5: Hypotheses Result

\begin{tabular}{|l|c|c|c|c|}
\hline \multicolumn{1}{|c|}{ Hypothesis } & t-Value & Coefficient & Remark & Summary \\
\hline $\begin{array}{l}\text { H1: Transformational entrepreneurship posi- } \\
\text { tively }\end{array}$ & 2.66 & 0.17 & Significant Positive & H1 Accepted \\
\hline $\begin{array}{l}\text { H2: Transformational entrepreneurship posi- } \\
\text { tively }\end{array}$ & 8.11 & 0.36 & Significant Positive & H2 Accepted \\
\hline $\begin{array}{l}\text { H3: Transformational entrepreneurship nega- } \\
\text { tively affects counterproductive work behavior }\end{array}$ & -3.95 & -0.26 & Significant Negative & H3 Accepted \\
\hline $\begin{array}{l}\text { H4: Organizational readiness for change posi- } \\
\text { tively }\end{array}$ & 13.78 & 0.60 & Significant Positive & H4 Accepted \\
\hline $\begin{array}{l}\text { H5: Counterproductive work behavior nega- } \\
\text { tively }\end{array}$ & -4.94 & -0.21 & Significant Negative & H5 Accepted \\
\hline
\end{tabular}

Chi-Square $=8.88, \mathrm{df}=10, \mathrm{p}$-value $=0.54380$, RMSEA $=0.00$ 
izations are ready to implement change, their employees are likely to show better performance.

Support for H4 (coefficient $=0.60, \mathrm{t}$-value $\geq 1.96, \mathrm{p}<$ 0.05 ) means organizational readiness for change positively affects employees' performance. This support shows that organizational readiness for change leads the employees to better performance as well, particularly task and contextual performances. It also indicates that employees consider change are beneficial for them and the risks associated with it are acceptable (Armenakis et al., 1993; Beer, 1980; Prochaska, et al., 1994; Spector, 1989), so they are committed to it by improving their efficacy to execute change that lead to better performance. Such commitment may be due to the fact that employees are confident their organization will help and assist them in overcoming challenges and obstacles related to change that can impede their performance. In addition, the finding of this study is consistent with what Weeks et al. (2004) found that when organizations are ready to implement change, their employees are likely to show better performance.

Support for H5 (coefficient $=-0,21$, t-value $\square-1.96$, p $<0.05$ ) means counterproductive work behavior negatively affects employees' performance. This support indicates that counterproductive work behavior leads the employees to worst performance, particularly task and contextual performances. Furthermore, it indicates that unhappy and dissatisfied employees who exhibit their protests toward their disagreements on change in such form as complaining on seemingly unimportant matters, making a problem bigger than it should be, and focusing on negative aspects of works may not carry out their job above and beyond what are required by job description, create both economic prosperity and social welfare, and solve new problems and overcome new challenges. Instead, they may intentionally slow down the work or even sabotage it. The finding of this study is also consistent with Sackett (2002) who found that counterproductive work behavior might result in lower employees' task and contextual performances, and with Greenidge et al. (2015) who found that counterproductive work behavior might lead to decreased contextual performance.

\section{Conclusion, Implications and Future Studies}

There are several interesting conclusion drawn from the above findings. The first conclusion is related to insignificant contribution of adaptive performance to employees' performance (adaptive performance was dropped from measurement model because it had SLF $<0.5$ ). According to Hesketh and Neal (1999), adaptive performance was an individual's ability to adjust and get necessary supports to carry out his or her job profile in a dynamic work situation. So, adaptive performance indicates employees' ability to overcome such volatile work conditions as related to implementing transformational entrepreneurship, in an effective and efficient manner (Baard, Rench, and Kozlowski, 2014). It involves employees' willingness to embark in new learning experience and get themselves comfortable with volatility in effectively and efficiently (Griffin, Parker, and Mason, 2010; Hollenbeck, LePine, and Ilgen, 1996), and to adjust their interpersonal behavior so they could work successfully with a wide range of peers and subordinates.

On the other hand, task performance emphasizes on behaviors directed at fulfilling job responsibilities as a part of job description. It focuses on effective executions on the assigned tasks to achieve the organization's objectives, and involves knowledge, skills and habits (Conway, 1999). Meanwhile, contextual performance refers to employees' voluntary behaviors that help other employees and or their organization achieve their goals (Bateman, \& Organ, 1983). These so-called prosocial or extra role behaviors are not necessarily mentioned in their job description, but such behaviors are conducted with the intention of supporting the advancement of fellow employees and or organization towards their objectives (Brief and Motowidlo, 1986).

This study implies that in times of change, particularly in a highly competitive but regulated industry like banking industry where this study took place, task and contextual performances were found to contribute much more significant to employees' performance compared to adaptive performance. The possible reason for this finding relates to continuous change banks have experienced in recent years that cause regulations to be regularly adjusted and make adaptability inherent in their daily operations. Consequently, being adaptable is not something employees have to perform as it is already built-in to their routine work behaviors and procedures. In the meantime, the demand for task performance is getting higher as the competition in banking industry is much tougher, especially with the eminent threat from financial technology. Contextual performance is also getting more relevant because of its prosocial nature, in which employees help each other and help their organization to reach their collective successes. Accordingly, for organizations operating in a highly regulated and competitive industry such as in banking industry, demonstrating task and contextual performances are increasingly critical to help organizations thrive in the competition. Management of such organizations should therefore direct their employees to achieve their respective targets and to help each other to achieve those targets, given that adaptability has already immersed into their daily routine.

The second conclusion is that all hypotheses examined in this study are all accepted. It means there are three paths from transformational entrepreneurship to employees' per- 
formance. There is a direct path and there are two indirect paths via readiness for change and counterproductive work behavior. The direct path has a coefficient of 0.36 , while the indirect paths via readiness for change has a coefficient of 0.102 (this coefficient is obtained from a multiplication of transformational entrepreneurship-readiness for change path of 0.17 and readiness for change-employees' performance path of 0.60 ) and the indirect paths via counterproductive work behavior has a coefficient of 0.0546 (this coefficient is obtained from a multiplication of transformational entrepreneurship-counterproductive work behavior path of -0.26 and readiness for change-employees' performance path of -0.21).

These findings imply the effectiveness of transformational entrepreneurship in directly affecting employees' performance, rather than go through readiness for change and counterproductive work behavior. Transformational entrepreneurship itself is essentially entrepreneurial activities that bring major changes in market and industry as well as in social and cultural life (Marmer, 2012). It puts more emphasis on stimulating socio-development in a dynamic manner (Mass and Paul, 2019), and it creates large, vibrant business that grow much beyond the scope of an individual's subsistence needs and provide jobs and income for others (Schoar, 2010). Transformation entrepreneurship generates employees' performance as it develops organization's market and industry, and thus gives much more opportunities for employees to perform. Accordingly, to improve employees' performance, management of the organizations needs to nurture and encourage transformational entrepreneurial activities among employees. These activities benefit not only the organizations where they work, but also themselves.

The above findings also imply that the effect transformational entrepreneurship has on readiness for change and counterproductive work behavior adds its impact on employees' performance. But, if we compare the direct effect of these three variables toward employees' performance, readiness for change comes up much more impactful than the other two. It shows that having employees ready for change can help them cope with such volatility and dynamics, more than avoiding or minimizing counterproductive work behavior, to reach better performance. Readiness for change itself involves shifting the mindsets and generating motivations to change; it involves change commitment and change efficacy (Weiner, 2009). Consequently, to enhance employees' performance, management of the organizations needs to urge employees' mind shift and boost their motivations toward change so they are committed and able to execute change when the time comes.

Future studies may be warranted in industries other than banking industry that have different characteristics of volatility and dynamics to empirically examine whether readiness for change comes up more impactful than trans- formational entrepreneurship and counterproductive work behavior. In addition, future studies may need to include internal and external situational factors, such as Denison, Hooijberg, Lane and Lief's (2012) corporate culture, and Dess and Beard's (1984) environmental dynamism, complexity and munificence as moderators to each of the three paths toward employees' performance to measure the extent these situational factors strengthen or weaken the effect of transformational entrepreneurship, readiness for change and counterproductive work behavior on employees' performance. Future studies may also need to consider a longitudinal approach to examine this study's causal-effect relationships. Although we hold that such relationships, specified based on literature, were plausible, we cannot demonstrate that contention empirically using cross-sectional data. In reality, it is possible that such relationships are reciprocally related over time, for example, between affects transformational entrepreneurship and employees' performance, that past employees' performance may affect subsequent transformational entrepreneurship.

\section{Literature}

Anderson, J.C. \& Gerbing, S.W. (1988). Structural equation modeling in practice: a review and recommended two-step approach. Psychological Bulletin, 103(3), 411-423. https://doi.org/10.1037/0033-2909.103.3.411

Armenakis, A, A., Harris, S.G., \& Mossholder, K.W. (1993). Creating readiness for organizational change. Human Relations 1993, 46, 681-703. https://doi. org/10.1177/001872679304600601

Baard, S. K., Rench, T. A., \& Kozlowski, S. W. (2014). Performance adaptation: A theoretical integration and review. Journal of Management, 40, 48-99. http://dx. doi.org/10.1177/0149206313488210

Bandalos, D.L. (2002). The Effects of item parceling on Goodness-of-Fit and Parameter Estimate bias in Structural Equation Modeling. Structural Equation Modeling, 9(1), 78-102. https://doi.org/10.1207/ S15328007SEM0901 5

Bateman, T.S., \& Organ, D.W. (1983). Job satisfaction and the good soldier: The relationship between affect and employee "citizenship". Academy of Management Journal, 26(1), 587-595. http://dx.doi. org $/ 10.2307 / 255908$

Beer, M. (1980). Organization change and development, A systems view. Santa Monica, California: Goodyear Publishing Company, Inc. https://doi. org/10.2307/257315

Bonini, S. \& Swartz, S., (2014). Profits with purpose: How organizing for sustainability can benefit the bottom line. McKinsey on Sustainability \& Resource Productivity. https://www.mckinsey.com/business-functions/sustainability/our-insights/profits-with-purpose-how-or- 
ganizing-for-sustainability-can-benefit-the-bottom-line

Brief, A. P., \& Motowidlo, .S. J. (1986). Prosocial organizational behaviors. Academy of Management Review, 11,710-725. https://doi.org/10.5465/ amr.1986.4283909

Conway, J.M. (1999). Distinguishing contextual performance from task performance for managerial jobs. Journal of Applied Psychology, 84(3), 3-13. https:// doi.org/10.1037/0021-9010.84.1.3

Denison, D., Hooijberg, R., Lane, N., \& Lief, C. (2012). Leading culture change in global organizations: Aligning culture and strategy. San Francisco: Jossey-Bass.

Dess, G.G., \& Beard, D.W. (1984). Dimensions of organizational task environments, Administrative Science Quarterly, 30, 336-349. https://doi. org/10.2307/2393080

Environmental Performance Index (EPI) (2020). Global metrics for the environment: Ranking country performance on sustainability issues. https://epi.yale. edu/\#: :text=Welcome-,About $\% 20$ the $\% 20$ EPI,environmental $\% 20$ health $\% 20$ and $\% 20$ ecosystem $\% 20$ vitality

Fornell, C. \& Larcker, D.F. (1981). Evaluating Structural Equation Models with Unobservable Variables and Measurement Error, Journal of Marketing Research, 18(1), 39-50. https://doi.org/10.2307/3151312

Greenidge, D., Devonish, D., \& Alleyne, P. (2014). The relationship between ability-based emotional intelligence and contextual performance and counterproductive work behaviors: A test of the mediating effects of job satisfaction. Human Performance, 27(3), 225-242. https://doi.org/10.1080/08959285.2014.913591

Griffin, M. A., Parker, S. K., \& Mason, C. (2010). Leader vision and the development of adaptive and proactive performance: A longitudinal study. Journal of Applied Psychology, 95, 174-182. https://doi.org/10.1037/ a0017263

Hair, J., Black,W., Babin, B.J., Anderson.R., \& Tatham, R. (2014). Multivariate data analysis. A global perspective. India: Pearson Prentice Hall.

Helmy, I, Adawiyah, W.R., \& Setyawati, H. A. (2020). Fostering Frontline Employees' Innovative Service Behavior: The Role of Workplace Friendship and Knowledge Sharing Process. Organizacija, 53(3), 185197. https://doi.org/10.2478/orga-2020-0012

Herrera, A.M. \& Lora, E., (2005). Why so small? Explaining the size of firms in Latin America. World Econo$m y, 28(7), 1005-1028$. https://doi.org/10.1111/j.14679701.2005.00718.x

Hesketh, B., \& Neal, A. (1999). Technology and performance. In D.R. Ilgen \& E.D. Pulakos (Eds) The changing nature of performance: Implications for staffing, motivation, and development, (pp. 21-55). San Fran- cisco, CA: Jossey-Bass.

Holt, D.T., Armenakis, A., Harris, S.G., \& Field H.S. (2007). Toward a comprehensive definition of readiness for change: A review of research and instrumentation. In W.A. Pasmore \& R.M. Woodman (Eds,), Research in organizational change and development (pp.289-336). Oxford, England: Elsevier. https://doi. org/10.1016/S0897-3016(06)16009-7

Hollenbeck, J. R., LePine, 3. A., \& Ilgen, D. R. (1996). Adapting to roles in decision-making teams. In K. R. Murphy (Ed.), Individual differences and behavior in organizations (pp. 300-333). San Francisco: JosseyBass.

Hunt, E. (1996). When should we shoot the messenger? Issues involving cognitive testing, public policy, and the law. Psychology, Public Policy and Law, 2, 486-505. https://doi.org/10.1037/1076-8971.2.3-4.486

Jöreskog, K. G. (2000). Latent Variables Scores and Their Uses, available at http://www.ssicentral.com/lisrel/advancedtopics.html

Jöreskog, K. G., Dag Sörbom, D. \& Walentin, F.Y. (2006), Latent Variables Scores and observational Residuals, Available at https://www.researchgate.net/publication/254378812_Latent_Variable_Scores_and_Observational Residuals

Kelloway, E. K., Francis, L., Prosser, M., \& Camerson, J. E. (2010). Counterproductive work behavior as protest. Human Resource Management Review, 20, 18-25. https://doi.org/10.1016/j.hrmr.2009.03.014

Klandermans, B. (1997). The social psychology of protest. Oxford: Blackwell.

Klandermans, B. (2002). How group identification helps to overcome the dilemma of collective action. American Behavioral Scientist, 45, 887-900. https://doi.org/10.1 177\%2F0002764202045005009

Koopmans L., Bernaards C.M., Hildebrandt V.H., van Buuren S., van der Beek A.J., de Vet H.C. (2014). Improving the individual work performance questionnaire using Rasch analysis. Journal of Applied Measurement, 15: 160-175.

Lewin, K. (1947). Frontiers in group dynamics: Concept, method and reality in social science; social equilibria and social change. Human Relations, 1, 5-41. http:// dx.doi.org/10.1177/001872674700100103

Lewin, K. (1951). Field theory in social science; selected theoretical paper (1st ed.). New York: Harper. Marmer, 2012, p. 2. https://doi.org/10.1177\% 2F000271625127600135

Maas, G., Lockyer, J., Jones, P. (2019). The journey of transformational entrepreneurship. @ The Author(s) 2019, G. Maas,P. Jones (eds), Transformational Entrepreneurship Practices, https://doi.org/10.1007/978-9030-11524-1_1

Mass, G. \& Jones, P. (2019). Transformational Entrepre- 
neurship Practices: Global Case Studies. Palgrave Macmillan. https://doi.org/10.1007/978-3-030-115241

Marmer, M. (2012). Transformational entrepreneurship: Where technology meets societal impact. Harvard Business Review, 2012 (April. 23). https://hbr. org/2012/04/transformational-entrepreneurs

McKinsey Global Survey Results. (2017). Available at https://www.mckinsey.com/business-functions/sustainability/our-insights/sustainabilitys-deepening-imprint

Pettigrew, A. (1987), Context and action in the transformation of the firm, Journal of Management Studies, 24 (6), 649-70. https://doi.org/10.1111/j.1467-6486.1987. tb00467.x

Pradhan, Rabindra. K. \& Lalatendu K. Jena. (2017). Employee Performance at Workplace Conceptual Model and Empirical Validation. Business Perspectives and Research, 5(1) 1-17. https://doi. org $/ 10.1177 / 2278533716671630$

Prochaska J.O., Velicer W.E., Rossi J.S., Goldstein MG, Marcus B.H., RaJiowski W., Eiore C., Harlow L.L., Redding C.A., Rosenbloom D., Rossi S.R. (1994). Stages of change and decisional balance for 12 problem behaviors. Health Psychology. 13:39-46. https:// doi.apa.org/doi/10.1037/0278-6133.13.1.39

Rhemtulla, M. (2016). Population performance of parceling strategies under measurement and Structural Model Misspecification. Psychological Methods, 21(1), 348 368. https://doi.apa.org/doi/10.1037/met0000072

Rigdon, E., Sarsted M. \& Ringle C. (2017). On Comparing Results from CB-SEM and PLS-SEM: Five Perspectives and Five Recommendation. Marketing-ZFP. 39(3), 4-16. http://dx.doi.org/10.15358/0344-13692017-3-4

Sackett, P. R. (2002). The structure of counterproductive work behaviors: Dimensionality and relationships with facets of job performance. International Journal of Selection and Assessment, 10, 5-11. http://dx.doi. org/10.1111/1468-2389.00189

Schoar, A. (2010). The divide between subsistence and transformational entrepreneurship. Innovation Policy and the Economy 10(1), 57-81. The University of Chicago Press. http://dx.doi.org/10.1086/605853

Shane, S. \& S. Venkataraman (2000). The promise of entrepreneurship as a field of research. Academy of Management Review, 25, 217-226. https://doi. org $/ 10.2307 / 259271$

Shaw, E., Carter, S. (2007). Social entrepreneurship: Theoretical antecedents and empirical analysis of entrepreneurial processes and outcomes. Journal of Small Business and Enterprise Development, 14(3), 418-34. http://dx.doi.org/10.1108/14626000710773529

Starik, M., \& Rands, G. P. (1995). The role of corporations in achieving ecological sustainability: Evaluating the
Environmental Performance of Corporations. Academy of Management Review, 20(4), 908-935. http://dx. doi.org/10.1108/14626000710773529

Spector, B.A. (1989), From bogged down to fired up: inspiring organizational change. Sloan Management Review, Summer, pp. 29-34, http://www. simpsonexecutivecoaching.com/pdf/orgchange/ bogged-down-fired-up-inspiring-organizational-change-bert-spector.pdf

Virmani, A., Lepineux, F. (2016). Aravind eye care system as Transformational entrepreneurship: Spiritual roots, Multi-dimensional impact. Philosophy of Management, 15, 83-94. http://dx.doi.org/10.1007/s40926016-0032-z

Viswesvaran, C., Schmidt, F. L., \& Ones, D. S. (1999). The role of halo error in interdimensional ratings: The case of job performance ratings examined via meta-analysis. Unpublished manuscript. In N. Anderson, D. S. Ones, H. K. Sinangil, \& C. Viswesvaran (Eds.), Handbook of Industrial, Work, \& Organizational Psychology Volume 1: Personnel Psychology (pp. 145-164). London, UK: Sage Publications.

Weiner, B.J. (2009). A theory of organization readiness for change. Implementation Science, 4, $67 \mathrm{https}$ ://doi. org/10.1186/1748-5908-4-67

Weeks, W. A., Roberts, J., Chonko, L. B., \& Jones, E. (2004). Organizational readiness for change, individual fear of change, and sales manager performance: An empirical investigation. Journal of Personal Selling \& Sales Management, 24, 7-18. https://doi.org/10.1080/ 08853134.2004.10749012

Weber, Olaf. (2017). Corporate sustainability and financial performance of Chinese banks. Sustainability Accounting, Management and Policy Journal, 8, (3), 358-385. https://doi.org/10.1108/SAMPJ-09-2016-0066

Febri Nila Chrisanty is a Ph.D student in University of Indonesia, Faculty Economics and Business, Depok, Indonesia. She completed her undergraduate degree at the Faculty of Economics, University of Trisakti, Indonesia, and her master's degree at the Magister Management, University of Indonesia, Indonesia. She has 18 years of practical experience in financial industry.

Michael Surya Gunawan is a Ph.D student in University of Indonesia, Faculty Economics and Business, Depok, Indonesia. He completed his undergraduate degree of Electrical Engineering at the 1986, University of Trisakti, and his master's degree at University of Indonesia. He has been for more than 30 years of practical experience in IT / ICT (Information Technology / Information \& Communication Technology) Industry. 
Retno W. Wijayanti is a Ph.D student in University of Indonesia, Faculty Economics and Business, Depok, Indonesia. She completed her undergraduate degree on Agribisnis at Bogor Agricultural Institute (IPB University), Indonesia, in 1988, and her master's degree at Drexell University, USA in 1997. She has 31 years of practical experience in Banking at PT. Bank Rakyat Indonesia (Persero), Tbk.

Budi W. Soetjipto is a vice rector of University of Pertamina, Faculty Economic and Business, Jakarta, Indonesia and also an associate professor in management at University of Indonesia, Faculty of Economics and Business, Depok, Indonesia. He completed his undergraduate degree at the Department of Management, University of Indonesia, and his master's and Ph.D degrees at Department of Management and Labor Relations, Cleveland State University, USA. He has 30 years of academic and practical experiences in the fields of human resources management, organizational behavior, and strategic management.(https://orcid.org/0000-0001-56700864). 


\section{Appendix A: Organizational Commitment Questionnaire (Meyer and Allen, 1991)}

\begin{tabular}{|c|c|c|c|}
\hline Construct & Dimension & Items & Measures \\
\hline \multirow{17}{*}{$\begin{array}{l}\text { Transformational } \\
\text { Entrepreneurship } \\
\text { (TE) }\end{array}$} & \multirow{6}{*}{$\begin{array}{l}\text { Human Cap- } \\
\text { ital Quality } \\
\text { (HCQ) }\end{array}$} & TE_QHC1 & Our employees demonstrate sufficient knowledge at work \\
\hline & & TE_QHC2 & Our employees are skillful at their work \\
\hline & & TE_QHC3 & Our employees show appropriate attitude at their work \\
\hline & & TE_QHC4 & Our employee consistently generates new ideas \\
\hline & & TE_QHC5 & Our employees perform to the best of their ability \\
\hline & & TE_QHC6 & Our employees constantly do their best \\
\hline & \multirow{6}{*}{$\begin{array}{l}\text { Risk Taking } \\
\text { \& Taking } \\
\text { Opportunity } \\
\text { (RTT) }\end{array}$} & $\begin{array}{l}\text { TE } \\
\text { RTT01 } \\
\end{array}$ & We continuously seek for new opportunities in the market \\
\hline & & $\begin{array}{l}\text { TE } \\
\text { RTT02 }\end{array}$ & We have to take risks to take the advantage of new opportunities \\
\hline & & $\begin{array}{l}\text { TE } \\
\text { RTT03 } \\
\end{array}$ & We believe changes in market creates new opportunities \\
\hline & & $\begin{array}{l}\text { TE } \\
\text { RTT04 }\end{array}$ & We tend to participate in high-risk projects \\
\hline & & $\begin{array}{l}\text { TE } \\
\text { RTT05 }\end{array}$ & We talk more about opportunities than problems. \\
\hline & & $\begin{array}{l}\text { TE } \\
\text { RTT06 }\end{array}$ & We believe risk is an inherent part of new opportunities \\
\hline & \multirow{5}{*}{$\begin{array}{l}\text { Evaluating } \\
\text { Changing } \\
\text { Condition } \\
\text { (ECC) }\end{array}$} & TE_ECC1 & $\begin{array}{l}\text { We gather relevant information to evaluate external changing condi- } \\
\text { tions }\end{array}$ \\
\hline & & TE_ECC2 & We collect information accordingly to understand market dynamics \\
\hline & & TE_ECC3 & We continuously evaluate every change in the market \\
\hline & & TE_ECC4 & We assess relevant information as a part of market evaluation \\
\hline & & TE_ECC5 & We evaluate market conditions using valid information \\
\hline \multirow{10}{*}{$\begin{array}{l}\text { Readiness for } \\
\text { Change (RC) }\end{array}$} & & RC_1 & People in this organization readily accept change \\
\hline & & RC_2 & Past Introduction of new technology have gone smoothly \\
\hline & & RC_3 & Clear business goals are guiding the introduction of the new technology \\
\hline & & RC_4 & The new technology will improve job quality in our organization \\
\hline & & RC_5 & The new technology will improve Job security \\
\hline & & RC_6 & People trust upper management to make technology decisions \\
\hline & & RC_7 & There is good communication between management and employees \\
\hline & & RC_8 & We have the money needed to invest in new technology \\
\hline & & RC_9 & Our employee are willing to be trained to work with new technology \\
\hline & & RC_10 & $\begin{array}{l}\text { The physical infrastructure of our workplace can readily accommodate } \\
\text { new technology }\end{array}$ \\
\hline \multirow{5}{*}{$\begin{array}{l}\text { Counterproduc- } \\
\text { tive Work Behav- } \\
\text { ior (CWB) }\end{array}$} & & CWB_1 & I complained about unimportant issues at work \\
\hline & & CWB_2 & I made problems at work bigger than they were \\
\hline & & CWB_3 & $\begin{array}{l}\text { I focused on the negative aspects of a situation at work instead of the } \\
\text { positive aspects }\end{array}$ \\
\hline & & CWB_4 & I talked to colleagues about the negative aspects of my work \\
\hline & & CWB_5 & $\begin{array}{l}\text { I talked to people outside of the organization about the negative as- } \\
\text { pects of my work }\end{array}$ \\
\hline
\end{tabular}




\section{Appendix A: Organizational Commitment Questionnaire (Meyer and Allen, 1991) (continues)}

\begin{tabular}{|c|c|c|c|}
\hline \multirow{20}{*}{$\begin{array}{l}\text { Employee Perfor- } \\
\text { mance (EP) }\end{array}$} & \multirow{5}{*}{$\begin{array}{l}\text { Task Perfor- } \\
\text { mance (TP) }\end{array}$} & EP_TP1 & I was able to plan my work so that I finished it on time \\
\hline & & EP_TP2 & I kept in mind the work result I needed to achieve \\
\hline & & EP_TP3 & I was able to distinguish main issues from side issues \\
\hline & & EP_TP4 & I was able to carry out my work well with minimal time and effort \\
\hline & & EP_TP5 & I planned my work optimally \\
\hline & \multirow{8}{*}{$\begin{array}{l}\text { Contextual } \\
\text { Perfor- } \\
\text { mance (CP) }\end{array}$} & EP_CP1 & $\begin{array}{l}\text { On my own initiative, I started new tasks when my old tasks were } \\
\text { completed }\end{array}$ \\
\hline & & EP_CP2 & I took on challenging tasks when these were available \\
\hline & & EP_CP3 & I worked on keeping my job-related knowledge up to date \\
\hline & & EP_CP4 & I worked on keeping my work skills up to date \\
\hline & & EP_CP5 & I came up with creative solutions for new problems \\
\hline & & EP_CP6 & I took on extra responsibilities \\
\hline & & EP_CP7 & I Continually sought new challenges in my work \\
\hline & & EP_CP8 & I actively participated in meetings and/or consultations \\
\hline & \multirow{7}{*}{$\begin{array}{l}\text { Adaptive } \\
\text { Perfor- } \\
\text { mance (AP) }\end{array}$} & EP_AP1 & $\begin{array}{l}\text { I use to perform well to mobilize collective intelligence for effective } \\
\text { team work }\end{array}$ \\
\hline & & EP_AP2 & $\begin{array}{l}\text { I could manage change in my job very well whenever the situation } \\
\text { demands. }\end{array}$ \\
\hline & & EP_AP3 & I can handle effectively my work team in the face of change. \\
\hline & & EP_AP4 & $\begin{array}{l}\text { I always believe that mutual understanding can lead to a viable solution } \\
\text { in organization }\end{array}$ \\
\hline & & EP_AP5 & $\begin{array}{l}\text { I use to lose my temper when faced with criticism from my team mem- } \\
\text { bers. (R) }\end{array}$ \\
\hline & & EP_AP6 & I am very comfortable with job flexibility. \\
\hline & & EP_AP7 & I use to cope well with organizational changes from time to time. \\
\hline
\end{tabular}




\section{Appendix B: Relationship of Construct Dimension Items Measures and SFL}

\begin{tabular}{|c|c|c|c|c|}
\hline Construct & Dimension & Items & Measures & SFL \\
\hline \multirow{17}{*}{$\begin{array}{l}\text { Transformational } \\
\text { Entrepreneurship }\end{array}$} & \multirow{6}{*}{$\begin{array}{l}\text { Human Cap- } \\
\text { ital Quality }\end{array}$} & TE_QHC1 & Our employees demonstrate sufficient knowledge at work & 0,689 \\
\hline & & TE_QHC2 & Our employees are skillful at their work & 0,800 \\
\hline & & TE_QHC3 & Our employees show appropriate attitude at their work & 0,829 \\
\hline & & TE_QHC4 & Our employee consistently generates new ideas & 0,779 \\
\hline & & TE_QHC5 & Our employees perform to the best of their ability & 0,922 \\
\hline & & TE_QHC6 & Our employees constantly do their best & 0,879 \\
\hline & \multirow{6}{*}{$\begin{array}{l}\text { Risk Taking } \\
\text { \& Taking } \\
\text { Opportunity }\end{array}$} & $\begin{array}{l}\text { TE_- } \\
\text { RTT01 }\end{array}$ & We continuously seek for new opportunities in the market & 0,665 \\
\hline & & $\begin{array}{l}\text { TE_- } \\
\text { RTT02 }\end{array}$ & $\begin{array}{l}\text { We have to take risks to take the advantage of new oppor- } \\
\text { tunities }\end{array}$ & 0,657 \\
\hline & & $\begin{array}{l}\text { TE_- } \\
\text { RTT03 }\end{array}$ & We believe changes in market creates new opportunities & 0,720 \\
\hline & & $\begin{array}{l}\text { TE_- } \\
\text { RTT04 }\end{array}$ & We tend to participate in high-risk projects & $\begin{array}{r}0,321 \text { (Not } \\
\text { Valid) }\end{array}$ \\
\hline & & $\begin{array}{l}\text { TE_- } \\
\text { RTT05 }\end{array}$ & We talk more about opportunities than problems. & 0,752 \\
\hline & & $\begin{array}{l}\text { TE_- } \\
\text { RTT06 }\end{array}$ & We believe risk is an inherent part of new opportunities & 0,764 \\
\hline & \multirow{5}{*}{$\begin{array}{l}\text { Evaluating } \\
\text { Changing } \\
\text { Condition }\end{array}$} & TE_ECC1 & $\begin{array}{l}\text { We gather relevant information to evaluate external chang- } \\
\text { ing conditions }\end{array}$ & 0,864 \\
\hline & & TE_ECC2 & $\begin{array}{l}\text { We collect information accordingly to understand market } \\
\text { dynamics }\end{array}$ & 0,917 \\
\hline & & TE_ECC3 & We continuously evaluate every change in the market & 0,880 \\
\hline & & TE_ECC4 & $\begin{array}{l}\text { We assess relevant information as a part of market evalua- } \\
\text { tion }\end{array}$ & 0,894 \\
\hline & & TE_ECC5 & We evaluate market conditions using valid information & 0,841 \\
\hline \multirow{10}{*}{$\begin{array}{l}\text { Readiness for } \\
\text { Change }\end{array}$} & & RC_1 & People in this organization readily accept change & 0,672 \\
\hline & & RC_2 & Past Introduction of new technology have gone smoothly & $\begin{array}{r}0,259 \text { (Not } \\
\text { Valid) }\end{array}$ \\
\hline & & RC_3 & $\begin{array}{l}\text { Clear business goals are guiding the introduction of the new } \\
\text { technology }\end{array}$ & 0,848 \\
\hline & & RC_4 & $\begin{array}{l}\text { The new technology will improve job quality in our organi- } \\
\text { zation }\end{array}$ & 0,860 \\
\hline & & RC_5 & The new technology will improve Job security & 0,744 \\
\hline & & RC_6 & $\begin{array}{l}\text { People trust upper management to make technology deci- } \\
\text { sions }\end{array}$ & 0,740 \\
\hline & & RC_7 & $\begin{array}{l}\text { There is good communication between management and } \\
\text { employees }\end{array}$ & 0,832 \\
\hline & & RC_8 & We have the money needed to invest in new technology & 0,570 \\
\hline & & RC_9 & $\begin{array}{l}\text { Our employee are willing to be trained to work with new } \\
\text { technology }\end{array}$ & 0,797 \\
\hline & & RC_10 & $\begin{array}{l}\text { The physical infrastructure of our workplace can readily } \\
\text { accommodate new technology }\end{array}$ & 0,675 \\
\hline
\end{tabular}




\section{Appendix B: Relationship of Construct Dimension Items Measures and SFL (continues)}

\begin{tabular}{|c|c|c|c|c|}
\hline \multirow{5}{*}{$\begin{array}{l}\text { Counterpro- } \\
\text { ductive Work } \\
\text { Behavior }\end{array}$} & & CWB_1 & I complained about unimportant issues at work & 0,591 \\
\hline & & CWB_2 & I made problems at work bigger than they were & 0,838 \\
\hline & & CWB_3 & $\begin{array}{l}\text { I focused on the negative aspects of a situation at work } \\
\text { instead of the positive aspects }\end{array}$ & 0,854 \\
\hline & & CWB_4 & I talked to colleagues about the negative aspects of my work & 0,904 \\
\hline & & CWB_5 & $\begin{array}{l}\text { I talked to people outside of the organization about the } \\
\text { negative aspects of my work }\end{array}$ & 0,862 \\
\hline \multirow{20}{*}{$\begin{array}{l}\text { Employee Perfor- } \\
\text { mance }\end{array}$} & \multirow{5}{*}{$\begin{array}{l}\text { Task Perfor- } \\
\text { mance }\end{array}$} & EP_TP1 & I was able to plan my work so that I finished it on time & 0,847 \\
\hline & & EP_TP2 & I kept in mind the work result I needed to achieve & 0,839 \\
\hline & & EP_TP3 & I was able to distinguish main issues from side issues & 0,845 \\
\hline & & EP_TP4 & $\begin{array}{l}\text { I was able to carry out my work well with minimal time and } \\
\text { effort }\end{array}$ & 0,847 \\
\hline & & EP_TP5 & I planned my work optimally & 0,863 \\
\hline & \multirow{8}{*}{$\begin{array}{l}\text { Contextual } \\
\text { Perfor- } \\
\text { mance }\end{array}$} & EP_CP1 & $\begin{array}{l}\text { On my own initiative, I started new tasks when my old tasks } \\
\text { were completed }\end{array}$ & $\begin{array}{r}0,339 \text { (Not } \\
\text { Valid) }\end{array}$ \\
\hline & & EP_CP2 & I took on challenging tasks when these were available & 0,820 \\
\hline & & EP_CP3 & I worked on keeping my job-related knowledge up to date & 0,870 \\
\hline & & EP_CP4 & I worked on keeping my work skills up to date & 0,882 \\
\hline & & EP_CP5 & I came up with creative solutions for new problems & 0,896 \\
\hline & & EP_CP6 & I took on extra responsibilities & 0,833 \\
\hline & & EP_CP7 & I Continually sought new challenges in my work & 0,846 \\
\hline & & EP_CP8 & I actively participated in meetings and/or consultations & 0,860 \\
\hline & \multirow{7}{*}{$\begin{array}{l}\text { Adaptive } \\
\text { Perfor- } \\
\text { mance }\end{array}$} & EP_AP1 & $\begin{array}{l}\text { I use to perform well to mobilize collective intelligence for } \\
\text { effective team work }\end{array}$ & 0,719 \\
\hline & & EP_AP2 & $\begin{array}{l}\text { I could manage change in my job very well whenever the } \\
\text { situation demands. }\end{array}$ & 0,882 \\
\hline & & EP_AP3 & I can handle effectively my work team in the face of change. & 0,720 \\
\hline & & EP_AP4 & $\begin{array}{l}\text { I always believe that mutual understanding can lead to a } \\
\text { viable solution in organization }\end{array}$ & 0,631 \\
\hline & & EP_AP5 & $\begin{array}{l}\text { I use to lose my temper when faced with criticism from my } \\
\text { team members. (R) }\end{array}$ & $\begin{array}{r}0,321 \text { (Not } \\
\text { Valid) }\end{array}$ \\
\hline & & EP_AP6 & I am very comfortable with job flexibility. & 0,627 \\
\hline & & EP_AP7 & $\begin{array}{l}\text { I use to cope well with organizational changes from time to } \\
\text { time. }\end{array}$ & $\begin{array}{r}0,178 \text { (Not } \\
\text { Valid) }\end{array}$ \\
\hline
\end{tabular}

